\title{
Efficacy of Different Washing Treatments on Quality of Button Mushrooms (A. bisporus)
}

\section{Gupta $P^{1 *}$ and Bhat $A^{2}$}

${ }^{1}$ Department of Food Science and Nutrition, Lovely Professional University, Punjab, India

${ }^{2}$ Division of Post-harvest Technology, Sher-e-Kashmir University of Agricultural Sciences and Technology of Jammu, Jammu, India

\begin{abstract}
To enhance the quality and to obtain a better colour, fresh button mushrooms were given washing treatments with different chemical solutions of different concentration for 10 minutes and stored under refrigerated conditions to check their shelf life. The chemicals used were citric acid $(0.5 \%, 1.5 \%, 2.5 \%), \mathrm{H}_{2} \mathrm{O}_{2}(1.5 \%, 2.5 \%, 3.5 \%)$ and EDTA $(2 \%, 4 \%, 6 \%)$. Of all the treatments used, $2.5 \%$ citric acid was found to be the most effective in controlling weight loss, maturity index and microbial growth for up to a period of 12 days and was found to be highly acceptable according to the scores after sensory evaluation. With the advancement in storage period, significant difference in the color values $\left(\mathrm{L}^{*}, \mathrm{a}^{*}\right.$ and $\left.\mathrm{b}^{*}\right)$ and browning index was observed and an increase in weight loss, maturity index and microbial growth of mushrooms was observed.
\end{abstract}

Keywords: Physiological weight loss; Maturity index; Microbial growth; Citric acid; Hydrogen peroxide; EDTA

\section{Introduction}

White button mushrooms also called as Agaricus bisporus are an important part of human diet since antiquity because of its attractive colour, flavor and aroma. Also the nutritional composition of white button mushrooms is high. Agaricus on fresh weight basis contains 2.9 percent crude protein 5 percent carbohydrate, 0.9 percent crude fibre, 0.8 percent ash and 0.3 percent fat Rai [1] $\mathrm{K}$ and $\mathrm{P}$ are the dominant elements among the minerals. $\mathrm{K}$ to $\mathrm{Na}$ ratio found in mushrooms is desirable for hypertension patients [2]. The white button mushrooms are low in calorie, where the carbohydrates are stored as glycogen, chitin and hemicellulose instead of starch. Mushrooms are deliciously palatable non-conventional source of protein, which can bridge the protein gapping in Indian diet [3]. But white button mushroom are highly perishable because of high respiration, which leads to color change due to enzymatic oxidation and decreases their marketability. Loss of whiteness during storage is particularly deleterious for the mushroom industry [4]. There are several indicators that determine the quality of mushrooms, such as visual appearance, size, colour, maturity stage, development stage, microbial growth and weight loss. Discoloration reactions of mushrooms are complex and depend on raw material condition, washing, cutting, handling and packaging practices and bacterial growth during storage. Of these, colour is the most important parameter because it is first perceived by consumers and discoloration decreases the commercial value [5]. Color, fresh and clean appearance and uniform closed buttons have high importance for mushroom quality and consumer preferences [6,7]. The maturity index of mushrooms is a sign of maturity which increases after harvest and can be observed on the basis of cap opening. A good quality mushroom should be free from open veils, disease, spots, insect injury and decay. Guthrie (1984) gave description about different stages of sporophore development in mushrooms which include 1) veil intact (tight), 2) veil intact (stretched), 3) veil partially broken( $<$ half), 4) veil partially broken (>half), 5) veil completely broken, 6) cap open, gills well exposed, 7) cap open, gill surface flat. Treatment with antibrowning agents is an effective and frequently employed method for controlling the enzymatic browning in several fresh-cut fruits and vegetables [8]. In order to improve the color and enhance the shelf life washing of mushrooms with various anti browning inhibitors is recommended. Citric acid is widely used as an additive and as an antimicrobial by virtue of their low $\mathrm{pH}$ in food industry. Brennan et al. [9] proposed washing with $40 \mathrm{~g} / \mathrm{L}$ citric acid in mushrooms to be sliced. Like citric acid EDTA is also has the potential to inhibit microbial growth [10]. The immersion in hydrogen peroxide solution followed by dipping in a solution of enzymatic browning inhibitor was found to be beneficial for extending the shelf life of whole mushrooms. The aim of the present study is to check the efficacy of different washing treatments for minimizing the color change, enhancing the shelf life and giving them a fresh appearance under refrigerated storage.

\section{Material and Methods}

Button mushrooms were procured from the department of Plant Pathology and the research was conducted in the department of Food Science and Technology, SKUAST-Jammu. Freshly harvested mushrooms of uniform size and intact veil were chosen and washed with tap water to remove surface contamination. After this, whole mushrooms were dipped in different browning inhibitor solutions viz., $\mathrm{T}_{1}\left(\mathrm{H}_{2} \mathrm{O}_{2}, 1.5 \%\right), \mathrm{T}_{2}\left(\mathrm{H}_{2} \mathrm{O}_{2}, 2.5 \%\right), \mathrm{T}_{3}\left(\mathrm{H}_{2} \mathrm{O}_{2}, 3.5 \%\right), \mathrm{T}_{4}$ (citric acid, $0.5 \%$ ), $\mathrm{T}_{5}$ (citric acid, 1.5\%), $\mathrm{T}_{6}$ (citric acid, $2.5 \%$ ), $\mathrm{T}_{7}$ (EDTA, $2 \%$ ), $\mathrm{T}_{8}$ (EDTA, 4\%) and $\mathrm{T}_{9}$ (EDTA, 6\%) for 10 minutes. The mushrooms were then surface dried, packed in PP with five pin holes on each packet and stored under refrigerated condition and evaluated for change in colour, veil opening, physiological weight loss, total plate count and sensorial changes after 3 days interval for up to a period of 12 days. Approximately, $100 \mathrm{~g}$ of mushroom per pack were taken for each treatment with four replicates.

\section{Maturity index}

The maturity index was measured on the basis of scale ranging

*Corresponding author: Gupta P, Department of Food Science and Nutrition, Lovely Professional University, Jalandhar-Delhi GT Road, Punjab-144411, India, Tel: +919419252003; E-mail: prerna.gskuastj@gmail.com

Received May 09, 2016; Accepted May 27, 2016; Published June 02, 2016

Citation: Gupta P, Bhat A (2016) Efficacy of Different Washing Treatments on Quality of Button Mushrooms (A. bisporus). J Food Process Technol 7: 590. doi:10.4172/2157-7110.1000590

Copyright: $\odot 2016$ Gupta P, et al. This is an open-access article distributed under the terms of the Creative Commons Attribution License, which permits unrestricted use, distribution, and reproduction in any medium, provided the original author and source are credited. 
from 1 (veil intact) to 7 (cap open, gills flat) as suggested by Guthire [11]. Veil opening rate can be used to characterize the aging of white mushrooms. It is defined as the ratio of the number of mushrooms with cap opening out to the total number of mushrooms. Randomly, six mushrooms were taken from a packet and were evaluated manually by visual observation.

\section{Physiological weight loss}

Weight loss was determined by weighing the contents of the package before and after storage and was expressed as the percent loss of weight with respect to the initial weight.

Weight loss $(\%)=\frac{\mathrm{W}_{\mathrm{i}}-\mathrm{W}_{\mathrm{f}}}{\mathrm{W}_{\mathrm{i}}}$

Where,

$\mathrm{W}_{\mathrm{i}}$ is the initial weight of the mushrooms before treatment

$\mathrm{W}_{\mathrm{f}}$ is the final weight of mushrooms after storage

\section{Microbial analysis}

Microbial analysis was done according to total plate count method using nutrient agar. Nutrient agar was prepared and sterilized in an autoclave at $121^{\circ} \mathrm{C}$ for 20 minutes. Serial dilution of mushrooms (up to six dilutions) was then carried out and $0.1 \mathrm{ml}$ of the aliquot was added on the petri plate containing nutrient agar as medium (using micropipette). The plates were then covered and sealed with the help of porcelain wax and incubated at $37^{\circ} \mathrm{C}$ for 48 hours. The total microbial count was recorded as cfug ${ }^{-1}[12]$.

\section{Color}

The surface colour of mushrooms was measured with the help Hunter Lab Mini Scan XE Colorimeter with an 8-mm-diameter diaphragm calibrated with a white tile $(X=81.1, Y=86.0$ and $Z=91.8)$ [6]. Where, $L^{*}$ indicates (whiteness/darkness), $a^{*}$ (greenness/redness) and $b^{\star}$ (yellowness/blueness). Colour was measured from all the three sides of mushrooms and mean value was taken.

\section{Browning index} [13]:

The browning index was calculated using the following expression

$$
B I=100 \times\left[\frac{X-0.31}{0.71}\right]
$$

Where,

$$
X=\frac{\left(a^{*}+1.75 \mathrm{~L}^{*}\right)}{\left(5.645 \mathrm{~L}^{*}+\mathrm{a}^{*}-3.012 \mathrm{~b}^{*}\right)}
$$

\section{Sensory analysis}

The sensory analysis of the treated mushrooms was done after three days interval. Mushrooms were slightly sautéed in little oil and a pinch of salt was added and they were evaluated on the basis of appearance, flavor, texture, taste and overall acceptability using 9-point hedonic scale from $9=$ like extremely to $1=$ dislike extremely. The data obtained was analyzed statistically.

\section{Statistical analysis}

The results were analyzed using Factorial Completely Randomized Design (FCRD).

\section{Results and Discussion}

The quality of fresh mushrooms is influenced by stage of development and pre-harvesting factors. In order to prevent the deterioration of mushrooms and to increase the shelf life, mushrooms were subjected to various postharvest treatments and changes in physiology and biochemical components were studied. The results obtained from present study are summarized here under: White button mushrooms of uniform size, intact veil and free from mechanical damage were selected. The most successful strategies aimed to prevent browning occurring on fresh-cut fruit and vegetables are based on treatments with reducing agents, acidifying agents, chelating substances and calcium solutions Martin-Diana et al. [14] Various chemical treatments helped in delaying cap opening and keeping the veil intact (Table 1). All the treatments were effective in keeping the veil intact up to $6^{\text {th }}$ day of storage. Among the various treatments used citric acid $(2.5 \%)$ was the most effective in delaying cap opening. However the mushrooms treated with $2.5 \%$ citric acid $\left(\mathrm{T}_{9}\right)$ recorded the lowest (1.19) veil opening (i.e. veil intact) whereas the highest maturity index of 2.11 was observed in $\mathrm{T}_{6}\left(6 \%\right.$ EDTA) on $3^{\text {rd }}$ day of storage. Maturity index increased with the increase in storage period with a value of 3.70 in $\mathrm{T}_{9}$ to 4.83 in $\mathrm{T}_{6}$ on $12^{\text {th }}$ day of storage Weight loss in mushrooms is a common phenomenon which occurs mainly due to moisture loss and loss of carbon reserves due to respiration $[15,16]$. Treatment of mushrooms with various chemicals had a significant effect in controlling weight loss and it might be because these treatments helped in reducing the rate of respiration and transpiration (Table 2). Use of citric acid and hydrogen peroxide was found to be effective in reducing weight loss as compared to EDTA. Bayoumi [17] also reported that $\mathrm{H}_{2} \mathrm{O}_{2}$ treatment significantly reduced fresh weight loss of pepper fruits during storage under room temperature and fridge conditions. The antimicrobial effect of citric acid, EDTA and $\mathrm{H}_{2} \mathrm{O}_{2}$ helped in controlling the bacterial growth. Among the various treatments citric acid was found to be most effective in inhibiting microbial growth (Table 3). On $3^{\text {rd }}$ day of storage it was $4.02 \mathrm{cfu} / \mathrm{g}$ in treatment $\mathrm{T}_{9}$ and on $12^{\text {th }}$ day of storage the total plate count was found to be $6.42 \mathrm{cfu} / \mathrm{g}$ in $\mathrm{T}_{9}$ whereas the count was highest in $\mathrm{T}_{6}(6 \%$ EDTA) ranging from $5.29 \mathrm{cfu} / \mathrm{g}$ on $3^{\text {rd }}$ day to $8.48 \mathrm{cfu} / \mathrm{g}$ on $12^{\text {th }}$ day of storage. The significant effect of citric acid in limiting the development of food spoilage and pathogenic

\begin{tabular}{|c|c|c|c|c|}
\hline \multirow[t]{2}{*}{ Treatment } & \multicolumn{4}{|c|}{ Storage period (days) } \\
\hline & 3 & 6 & 9 & 12 \\
\hline $\begin{array}{l}\mathrm{T}_{1} \\
\left(1.5 \% \mathrm{H}_{2} \mathrm{O}_{2}\right)\end{array}$ & 1.42 & 2.60 & 3.75 & 4.25 \\
\hline $\begin{array}{l}\mathrm{T}_{2} \\
\left(2.5 \% \mathrm{H}_{2} \mathrm{O}_{2}\right)\end{array}$ & 1.33 & 2.48 & 3.61 & 4.13 \\
\hline $\begin{array}{l}\mathrm{T}_{3} \\
\left(3.5 \% \mathrm{H}_{2} \mathrm{O}_{2}\right)\end{array}$ & 1.24 & 2.32 & 3.45 & 3.75 \\
\hline $\begin{array}{l}\mathrm{T}_{4} \\
(2 \% \text { EDTA })\end{array}$ & 1.36 & 2.48 & 3.80 & 4.28 \\
\hline $\begin{array}{l}\mathrm{T}_{5} \\
(4 \% \text { EDTA) }\end{array}$ & 1.62 & 2.67 & 4.05 & 4.46 \\
\hline $\begin{array}{l}\mathrm{T}_{6} \\
(6 \% \text { EDTA })\end{array}$ & 2.11 & 3.46 & 4.29 & 4.83 \\
\hline $\begin{array}{l}\mathrm{T}_{7} \\
(0.5 \% \text { C.A })\end{array}$ & 1.36 & 2.52 & 3.35 & 4.07 \\
\hline $\begin{array}{l}\mathrm{T}_{8} \\
(1.5 \% \text { C.A })\end{array}$ & 1.28 & 2.38 & 3.26 & 3.82 \\
\hline $\begin{array}{l}\mathrm{T}_{9} \\
(2.5 \% \text { C.A })\end{array}$ & 1.19 & 2.41 & 3.31 & 3.70 \\
\hline
\end{tabular}
microorganisms is widely accepted $[18,19]$. The total microbial

Table 1: Change in the maturity index of mushrooms under refrigerated condition. 
Citation: Gupta P, Bhat A (2016) Efficacy of Different Washing Treatments on Quality of Button Mushrooms (A. bisporus). J Food Process Technol 7: 590. doi:10.4172/2157-7110.1000590

Page 3 of 5

\begin{tabular}{|l|c|c|c|c|}
\hline \multirow{2}{*}{ Treatment } & \multicolumn{4}{|c|}{ Storage period (days) } \\
\cline { 2 - 5 } & $\mathbf{3}$ & $\mathbf{6}$ & $\mathbf{9}$ & $\mathbf{1 2}$ \\
\hline $\begin{array}{l}\mathrm{T}_{1} \\
\left(1.5 \% \mathrm{H}_{2} \mathrm{O}_{2}\right)\end{array}$ & 0.42 & 1.72 & 3.47 & 4.19 \\
\hline $\mathrm{T}_{2}{ }_{\left(2.5 \% \mathrm{H}_{2} \mathrm{O}_{2}\right)}$ & 0.49 & 1.24 & 3.12 & 3.27 \\
\hline $\begin{array}{l}\mathrm{T}_{3} \\
\left(3.5 \% \mathrm{H}_{2} \mathrm{O}_{2}\right)\end{array}$ & 0.34 & 0.68 & 1.33 & 2.76 \\
\hline $\begin{array}{l}\mathrm{T}_{4} \\
(2 \% \mathrm{EDTA})\end{array}$ & 0.97 & 1.89 & 3.52 & 5.8 \\
\hline $\mathrm{T}_{5}$ \\
$(4 \% \mathrm{EDTA})$
\end{tabular}

\begin{tabular}{|c|c|c|c|}
\hline \multirow[t]{2}{*}{ Treatment } & \multicolumn{3}{|c|}{ Storage period (days) } \\
\hline & 3 & 9 & 12 \\
\hline $\begin{array}{l}\mathrm{T}_{1} \\
\left(1.5 \% \mathrm{H}_{2} \mathrm{O}_{2}\right)\end{array}$ & 5.23 & 6.19 & 7.65 \\
\hline $\begin{array}{l}\mathrm{T}_{2} \\
\left(2.5 \% \mathrm{H}_{2} \mathrm{O}_{2}\right)\end{array}$ & 4.85 & 5.17 & 7.42 \\
\hline $\begin{array}{l}\mathrm{T}_{3} \\
\left(3.5 \% \mathrm{H}_{2} \mathrm{O}_{2}\right)\end{array}$ & 4.25 & 6.25 & 7.13 \\
\hline $\begin{array}{l}\mathrm{T}_{4} \\
(2 \% \text { EDTA })\end{array}$ & 4.82 & 6.59 & 7.54 \\
\hline $\begin{array}{l}\mathrm{T}_{5} \\
(4 \% \text { EDTA })\end{array}$ & 5.08 & 7.10 & 8.35 \\
\hline $\begin{array}{l}\mathrm{T}_{6} \\
(6 \% \text { EDTA) }\end{array}$ & 5.29 & 7.32 & 8.48 \\
\hline $\begin{array}{l}\mathrm{T}_{7} \\
(0.5 \% \text { C.A })\end{array}$ & 4.33 & 6.48 & 7.27 \\
\hline $\begin{array}{l}T_{8} \\
(1.5 \% \text { C.A })\end{array}$ & 4.16 & 5.2 & 6.81 \\
\hline$T_{9}$ & 4.06 & 4.58 & 6.42 \\
\hline
\end{tabular}

$(2.5 \%$ C.A)

All values are mean significant values, C.D $(p=0.05)$, Treatment $=0.10$ Storage $=0.08, \mathrm{~T} \times \mathrm{S}=0.16$

Table 3: Microbial count in white button mushrooms (cfug-1) stored under refrigerated condition.

count though increased with storage, but was lesser than the count of ISI specification (IS: 7463-2004) [20]. All the treatments helped in maintaining the whiteness of mushrooms. Though with the increase in storage period the whiteness decreased and as storage progressed, the $\mathrm{L}^{*}$ value (lightness/darkness) decreased and $\mathrm{a}^{*}$ (redness/greenness) and $b^{\star}$ value (yellowness/blueness) increased. The rate of browning during storage might be influenced by the length of immersion of samples in the treatment solution. The initial value as observed for colour of fresh mushrooms was of $\mathrm{L}^{\star}$ value equal to 86.32 , $\mathrm{a}^{\star}$ value equal to 0.15 and $\mathrm{b}^{*}$ value equal to 2.12 . Among the various treatments used, $3.5 \% \mathrm{H}_{2} \mathrm{O}_{2}$ was the most effective in retaining the whiteness of mushrooms because of its bleaching effect (Table 4). Treatment with high concentration of citric acid led to slight change in color of mushrooms to yellow, though browning was significantly controlled and BI was effectively reduced during storage (Table 5). The browning index of mushrooms is related to change in color of mushrooms. As the $\mathrm{L}^{\star}$ value decreased and $\mathrm{a}^{*}$ and $\mathrm{b}^{*}$ value increased, the browning index increased. Brennan et al. (2000) also observed a yellowing of the surface cap when whole mushrooms were washed with $40 \mathrm{~g} / \mathrm{L}$ citric acid for $10 \mathrm{~min}$. However, these authors proposed this treatment to reduce microbial counts of mushrooms before slicing, having no deleterious effect on the sensory property of sliced mushrooms after cooking. Erbay et al. [21] also documented that treatment with citric acid showed the least reduction in $\mathrm{L}^{*}$ value since the beginning of storage and decreased when storage progressed. Appearance of mushrooms is one of the important quality

\begin{tabular}{|c|c|c|c|c|c|}
\hline \multirow[t]{2}{*}{ Treatment } & & \multicolumn{4}{|c|}{ Storage period (days) } \\
\hline & & 3 & 6 & 9 & 12 \\
\hline $\begin{array}{l}\mathrm{T}_{1} \\
\left(1.5 \% \mathrm{H}_{2} \mathrm{O}_{2}\right)\end{array}$ & $\begin{array}{l}L^{*} \\
a^{*} \\
b^{*}\end{array}$ & $\begin{array}{c}83.21 \\
0.70 \\
6.16\end{array}$ & $\begin{array}{c}81.64 \\
1.13 \\
13.22\end{array}$ & $\begin{array}{c}80.47 \\
2.23 \\
19.25\end{array}$ & $\begin{array}{c}77.63 \\
4.53 \\
27.35\end{array}$ \\
\hline $\begin{array}{l}\mathrm{T}_{2} \\
\left(2.5 \% \mathrm{H}_{2} \mathrm{O}_{2}\right)\end{array}$ & $\begin{array}{l}L^{*} \\
a^{*} \\
b^{*}\end{array}$ & $\begin{array}{c}84.12 \\
0.81 \\
4.18\end{array}$ & $\begin{array}{c}81.67 \\
1.47 \\
9.26\end{array}$ & $\begin{array}{c}80.19 \\
2.19 \\
13.76\end{array}$ & $\begin{array}{c}78.21 \\
2.63 \\
28.42\end{array}$ \\
\hline $\begin{array}{l}\mathrm{T}_{3} \\
\left(3.5 \% \mathrm{H}_{2} \mathrm{O}_{2}\right)\end{array}$ & $\begin{array}{l}L^{*} \\
a^{*} \\
b^{*}\end{array}$ & $\begin{array}{c}84.64 \\
0.75 \\
3.39\end{array}$ & $\begin{array}{c}83.54 \\
1.26 \\
9.13\end{array}$ & $\begin{array}{c}81.49 \\
2.13 \\
13.67\end{array}$ & $\begin{array}{c}79.75 \\
2.33 \\
23.67\end{array}$ \\
\hline $\begin{array}{l}\mathrm{T}_{4} \\
(2 \% \text { EDTA })\end{array}$ & $\begin{array}{l}L^{*} \\
a^{*} \\
b^{*}\end{array}$ & $\begin{array}{c}84.32 \\
0.51 \\
6.68\end{array}$ & $\begin{array}{c}82.68 \\
1.22 \\
11.79\end{array}$ & $\begin{array}{c}80.29 \\
2.60 \\
20.21\end{array}$ & $\begin{array}{c}78.39 \\
4.59 \\
33.85\end{array}$ \\
\hline $\begin{array}{l}\mathrm{T}_{5} \\
(4 \% \text { EDTA })\end{array}$ & $\begin{array}{l}L^{*} \\
a^{*} \\
b^{*}\end{array}$ & $\begin{array}{c}83.41 \\
0.75 \\
8.37\end{array}$ & $\begin{array}{c}81.10 \\
2.19 \\
15.71\end{array}$ & $\begin{array}{c}78.41 \\
2.30 \\
25.80\end{array}$ & $\begin{array}{c}77.62 \\
3.28 \\
34.56\end{array}$ \\
\hline $\begin{array}{l}T_{6} \\
(6 \% \text { EDTA })\end{array}$ & $\begin{array}{l}L^{*} \\
a^{*} \\
b^{*}\end{array}$ & $\begin{array}{c}83.29 \\
1.06 \\
8.64\end{array}$ & $\begin{array}{c}80.61 \\
2.59 \\
16.63\end{array}$ & $\begin{array}{c}79.29 \\
4.29 \\
27.39\end{array}$ & $\begin{array}{c}77.23 \\
6.07 \\
35.97\end{array}$ \\
\hline $\begin{array}{l}\mathrm{T}_{7} \\
(0.5 \% \text { C.A) }\end{array}$ & $\begin{array}{l}L^{*} \\
a^{*} \\
b^{*}\end{array}$ & $\begin{array}{c}84.29 \\
0.73 \\
3.38\end{array}$ & $\begin{array}{c}82.61 \\
1.21 \\
7.60\end{array}$ & $\begin{array}{c}81.54 \\
1.52 \\
12.73\end{array}$ & $\begin{array}{c}79.79 \\
2.42 \\
21.81\end{array}$ \\
\hline $\begin{array}{l}\mathrm{T}_{8} \\
(1.5 \% \text { C.A) }\end{array}$ & $\begin{array}{l}L^{*} \\
a^{*} \\
b^{*}\end{array}$ & $\begin{array}{c}83.51 \\
1.41 \\
4.20\end{array}$ & $\begin{array}{c}82.76 \\
1.46 \\
8.18\end{array}$ & $\begin{array}{c}79.16 \\
1.51 \\
13.39\end{array}$ & $\begin{array}{c}77.63 \\
2.46 \\
19.13\end{array}$ \\
\hline $\begin{array}{l}\mathrm{T}_{9} \\
(2.5 \% \text { C.A })\end{array}$ & $\begin{array}{l}L^{*} \\
a^{*} \\
b^{*}\end{array}$ & $\begin{array}{c}83.24 \\
0.81 \\
5.57\end{array}$ & $\begin{array}{c}82.18 \\
1.18 \\
9.61\end{array}$ & $\begin{array}{c}81.63 \\
2.34 \\
15.58\end{array}$ & $\begin{array}{c}78.73 \\
2.77 \\
25.30\end{array}$ \\
\hline
\end{tabular}

All values are mean significant values, $L^{*}$ (Whiteness/darkness), $a^{*}$ (redness/ greenness), $b^{*}$ (yellowness/blueness) C.D $(p=0.05)$

Table 4: Color changes in mushrooms stored under refrigerated conditions.

\begin{tabular}{|c|c|c|c|c|}
\hline \multirow[t]{2}{*}{ Treatment } & \multicolumn{4}{|c|}{ Storage period (days) } \\
\hline & 3 & 6 & 9 & 12 \\
\hline $\begin{array}{l}\mathrm{T}_{1} \\
\left(1.5 \% \mathrm{H}_{2} \mathrm{O}_{2}\right)\end{array}$ & 1.94 & 5.14 & 6.89 & 11.20 \\
\hline $\begin{array}{l}\mathrm{T}_{2} \\
\left(2.5 \% \mathrm{H}_{2} \mathrm{O}_{2}\right)\end{array}$ & 1.35 & 3.08 & 4.89 & 11.13 \\
\hline $\begin{array}{l}\mathrm{T}_{3} \\
\left(3.5 \% \mathrm{H}_{2} \mathrm{O}_{2}\right)\end{array}$ & 1.10 & 2.97 & 4.76 & 8.75 \\
\hline $\begin{array}{l}\mathrm{T}_{4} \\
(2 \% \text { EDTA })\end{array}$ & 2.03 & 3.86 & 7.37 & 9.47 \\
\hline $\begin{array}{l}\mathrm{T}_{5} \\
(4 \% \text { EDTA })\end{array}$ & 2.63 & 5.52 & 9.85 & 14.41 \\
\hline $\begin{array}{l}T_{6} \\
(6 \% \text { EDTA })\end{array}$ & 2.78 & 5.98 & 10.78 & 15.94 \\
\hline $\begin{array}{l}T_{7} \\
(0.5 \% \text { C.A) }\end{array}$ & 1.10 & 2.51 & 4.30 & 8.01 \\
\hline $\begin{array}{l}T_{8} \\
(1.5 \% \text { C.A) }\end{array}$ & 1.49 & 2.94 & 6.08 & 7.12 \\
\hline $\begin{array}{l}T_{9} \\
(2.5 \% \text { C.A })\end{array}$ & 1.78 & 3.15 & 5.47 & 9.69 \\
\hline
\end{tabular}

All values are mean significant values, C.D $(p=0.05)$, Treatment $=0.10$, Storage $=0.08, \mathrm{~T} \times \mathrm{S}=0.16$

Table 5: Change in browning index value of mushrooms stored under refrigerated condition. 
Citation: Gupta P, Bhat A (2016) Efficacy of Different Washing Treatments on Quality of Button Mushrooms (A. bisporus). J Food Process Technol 7: 590. doi:10.4172/2157-7110.1000590

Page 4 of 5

\begin{tabular}{|c|c|c|c|c|c|}
\hline Treatment & Appearance & Flavor & Texture & Taste & Overall acceptability \\
\hline $\begin{array}{l}\mathrm{T}_{1} \\
\left(1.5 \% \mathrm{H}_{2} \mathrm{O}_{2}\right)\end{array}$ & 6.91 & 6.93 & 6.80 & 6.80 & 6.85 \\
\hline $\begin{array}{l}\mathrm{T}_{2} \\
\left(2.5 \% \mathrm{H}_{2} \mathrm{O}_{2}\right)\end{array}$ & 7.06 & 7.03 & 7.17 & 7.00 & 7.06 \\
\hline $\begin{array}{l}\mathrm{T}_{3} \\
\left(3.5 \% \mathrm{H}_{2} \mathrm{O}_{2}\right)\end{array}$ & 7.40 & 7.37 & 7.35 & 7.28 & 7.21 \\
\hline $\begin{array}{l}\mathrm{T}_{4} \\
(2 \% \text { EDTA })\end{array}$ & 6.94 & 6.96 & 7.04 & 6.75 & 6.92 \\
\hline $\begin{array}{l}\mathrm{T}_{5} \\
(4 \% \text { EDTA) }\end{array}$ & 6.82 & 6.61 & 6.70 & 6.10 & 6.37 \\
\hline $\begin{array}{l}\mathrm{T}_{6} \\
(6 \% \text { EDTA })\end{array}$ & 6.63 & 6.40 & 6.33 & 6.15 & 6.41 \\
\hline $\begin{array}{l}\mathrm{T}_{7} \\
(0.5 \% \text { C.A })\end{array}$ & 6.93 & 7.27 & 6.91 & 6.88 & 6.99 \\
\hline $\begin{array}{l}\mathrm{T}_{8} \\
(1.5 \% \text { C.A) }\end{array}$ & 7.16 & 7.52 & 7.05 & 7.12 & 7.21 \\
\hline $\begin{array}{l}\mathrm{T}_{9} \\
(2.5 \% \text { C.A })\end{array}$ & 7.36 & 7.64 & 7.38 & 7.38 & 7.45 \\
\hline C.D. $(p=0.05)$ & $\begin{array}{c}\text { Treatment }=0.08 \\
\text { Storage }=0.04 \\
T \times S=0.20\end{array}$ & $\begin{array}{c}\text { Treatment }=0.11 \\
\text { Storage }=0.07 \\
T \times S=0.25\end{array}$ & $\begin{array}{c}\text { Treatment }=\mathrm{N} . \mathrm{S} \\
\text { Storage }=0.90 \\
\mathrm{~T} \times \mathrm{S}=\mathrm{N} . \mathrm{S}\end{array}$ & $\begin{array}{c}\text { Treatment }=0.19 \\
\text { Storage }=0.10 \\
\text { T x S }=0.38\end{array}$ & $\begin{array}{c}\text { Treatment }=0.15 \\
\text { Storage }=0.08 \\
\text { T x S }=0.30\end{array}$ \\
\hline
\end{tabular}

Table 6: Sensory evaluation of mushrooms stored under refrigerated condition.

attribute. At the beginning, on the basis of hedonic rating, the scores of sensory evaluation were: (8.85) for appearance, (8.57) for flavor, (8.44) for texture and (8.72) for taste and (8.64) for overall acceptability. Treatment with various chemicals helped in preventing off-odor in mushrooms during storage. Among the different treatments, citric acid helped in prolonging its shelf life, maintaining, freshness and eating quality during storage at refrigerated temperatures as compared to control. These results are in agreement with the findings of Rosario [22] who observed that increasing storage time cause progressive degradation, which leads to decrease in overall acceptability. The scores decreased with storage as the mushrooms were not liked by panelists as evident by change in colour of mushrooms and increased maturity index (Table 6). Loss of firmness was observed in all the treatments. This loss of firmness is a gradual process of catabolism catalyzed by different enzymes.

\section{Conclusion}

To maintain the quality and availability of mushrooms and to extend its acceptability, they were treated with aqueous solution of different chemicals and stored under refrigerated condition. Treatment of mushrooms with various chemicals viz: hydrogen peroxide, ethylene diaminetretaacetic acid and citric acid were effective in retaining the quality parameters of mushrooms. From the observations it was observed that citric acid is the most effective in controlling weight loss, maturity index and microbial growth. Citric acid showed slightly antibacterial potential but induced a slight yellowness on mushroom surface. It was also observed that higher concentration of citric acid led to more yellowness on the surface of mushrooms as recorded by hunter color lab but browning was significantly reduced. Hydrogen peroxide is more effective in maintaining the whiteness of mushrooms and was found to be at par with citric acid. From different concentrations of EDTA used it was recorded that the lesser percentage of EDTA is more effective. Jafri et al. [23] in 2013 had showed the senescence inhibition of oyster mushrooms by the combined effect of chemical treatment and MAP, resulting in maintenance of tissue firmness and sensory quality, inhibition of lipid peroxidation and better retention of phenolics and antioxidant ability as compared to the control samples [24-28]. These results suggested that a combination of chemical treatment and MAP had good promise in maintaining oyster mushroom quality and extending their postharvest life up to 25 days when stored at $4^{\circ} \mathrm{C}$. Another important observation made was that the use of chemical treatment alone was more effective than the use of MAP alone. High weight loss with visible evidence of deterioration and senescence were the main effects observed in the chemically untreated samples.

\section{Acknowledgment}

This study was funded by Sher-e-Kashmir University of Agricultural Sciences and Technology of Jammu, Chatha, and Jammu.

\section{References}

1. Rai RD (1995) Nutritional and medicinal value of mushrooms. Advances in horticulture Mushroom 13: 537-551.

2. Chang ST, Miles PG (1989) Biology and cultivation of edible mushrooms Academic Press London.

3. Desayi D (2012) Development and sensory evaluation of mushroom fortified noodles. Int J Food Agri Vet Sci 2: 187-189.

4. Jolivet S, Arpin NL, Wichers HJ, Pellon G (1998) Agaricus bisporus browning A review. Mycol Res 102: 1459-1483.

5. Weijn A, Tomassen MMM, Bastiaan-Net S, Wigham MLI, Boer EPJ, et al. (2011) A new method to apply and quantify bruising sensitivity of button mushrooms. Food Sci Technol 47: 308-314.

6. Gonzalez- Fandos E, Gimenez M, Olarte C, Sanz S (2000) Effect of packaging condition on the growth of microorganisms and the quality characteristics of fresh mushrooms ( $A$. bisporus) stored at inadequate temperature. J Applied Microbiology 889: 624-632

7. Vizhanyo $T$, Jozsef $F$ (2000) Enhancing color differences in images of diseased mushrooms. Comp Elec Agri 26: 187-198.

8. Suttirak W, Manurakchinakor S, Walailak J (2010) Potential application of ascorbic acid citric acid and oxalic acid for browning inhibition in fresh-cut fruits and vegetables. Sci Technol 7: 5-14.

9. Brennan MH, Le Port G, Gormley TR (2000) Post harvest treatment with citric acid or hydrogen peroxide to extend the shelf life of fresh sliced mushrooms. Lebensmittel Wissenschaft Technol 33: 285-289.

10. Breenan HM, Gormley RT (1998) Extending the shelf life of fresh sliced mushrooms. The National Food Centre Dunsinea Castleknock Dublin.

11. Guthire BD (1984) Studies on the control of bacterial deterioration of fresh washed mushrooms (Agaricus bisporus/ brunescens). The Pennsylvania State University. 
Citation: Gupta P, Bhat A (2016) Efficacy of Different Washing Treatments on Quality of Button Mushrooms (A. bisporus). J Food Process Technol 7: 590. doi:10.4172/2157-7110.1000590

12. Nwachukwu E, Ezeigbo CG (2013) Changes in the microbial population of pasteurized sourop juice treated with benzoate and lime during storage. African J Microbiology Research 7: 3992-3995.

13. Bozkurt H, Bayram M (2006) Color and textural attributes of sucuk during ripening. J Meat Science73: 344-350.

14. Martin-Diana AB, Rico D, Frias JM, Barat JM, Henehan GT M et al. (2007) Calcium for extending the shelf life of fresh whole and minimally processed fruits and vegetables: a review. Trend Food Sci Tech 18: 210-218.

15. Jauathunge L, Illeperuma $C$ (2001) Extension of post harvest life of oyster mushroom under ambient conditions by modified atmosphere packaging. Journal Tropical Agricultural Research 13:78-89.

16. Du J, Fu M, Li M, Xia W (2007) Effect of chlorine dioxide gas on post harvest physiology and storage quality of green bell pepper (Capsicum frutescens $L$ var Longrum). Agricultural Sciences in China 6: 214-219.

17. Bayoumi AY (2008) Improvement of post harvest keeping quality of white pepper fruits (Capsicum annuum $\mathrm{L}$ ) by hydrogen peroxide treatment under storage conditions. Acta Biologica Szegdiensis 52: 7-15.

18. Banwart GJ (1989) Basic food microbiology. The University of Michigan Avi Publishing Co Westport Conn.

19. Beuchat LR, Golden DA (1989) Antimicrobials occurring naturally in food. Food Technology 43: 134-142.

20. Singh M, Vijay B, Kamal S, Wakcaure GC (2011) Mushrooms-cultivation, marketing and consumption. Directorate of Mushroom Research, Solan .
21. Erbay B, Kucukoner E, Orhan H (2011) Colour and some physical properties of frozen mushroom (Agaricus bisporus) which dipped in different antioxidant solutions. International J Health and Nutrition.

22. Rosario MJG (1996) Formulation of ready to drink blends from fruits and vegetable juices. J Philippines Agriculture Research 9: 201-209.

23. Jafri M, Jha A, Bunkar DS, Ram RC (2013) Quality retention of oyster mushrooms (Pleurotus florida) by a combination of chemical treatments and modified atmosphere packaging. Post Harv Biol Technol 76: 112-118.

24. Langnika C, Zhang M, Wang S (2011) Effect of high argon pressure and modified atmosphere packaging on the white mushroom (Agaricus bisporus) physico-chemical and microbiological properties. J Food and Nutrition Research 50: 167-176.

25. Mattila P, Konko K, Eurola M (2001) Contents of vitamins mineral elements and some phenolic compounds in cultivated mushrooms. J Agricultural and Food Chemistry 49: 2343-2348.

26. Ranganna S (2005) Sensory evaluation handbook of analysis and quality control for fruit and vegetables products. Tata Mc Graw Hill Education Private Ltd New York USA.

27. Miller CF, Cooke HP, Choi WS (1994) Enzymatic browning control in minimally processed mushrooms. J Food Science 59: 1042-1047.

28. Simon A, Gonzalez-Fandos E (2009) Effect of washing with citric acid or sodium hypochlorite on the visual and microbiological quality of mushrooms (Agaricus bisporus). J Food Quality 33: 273-285. 